\title{
The Bisphosphonates versus Denosumab Efficiency in Postmenopausal Osteoporosis Treatment
}

\author{
Lorena Ciumărnean ${ }^{1,2}$, Mircea Vasile Milaciu², Mirela Georgiana Alb ${ }^{3}$, Rareș Tiberiu Moldovan4, Dorel \\ Partene Sâmpelean ${ }^{1,2}$ \\ 1. CF Clinical Hospiatl, Cluj-Napoca, Romania \\ 2. $4^{\text {th }}$ Medical Clinic, "Iuliu Hațieganu" University of Medicine and Pharmacy, Cluj-Napoca, Romania \\ 3. Regional Institute of Gastroenterology and Hepatology "Prof. Dr. Octavian Fodor”, Cluj-Napoca, Romania \\ 4. Oncology Institute "Prof. Dr. Ion Chiricuță”, Cluj-Napoca, Romania
}

\begin{abstract}
Introduction. Osteoporosis is a frequently ignored disease, that has the potential to develop an adverse outcome, leading to complications that lower patients' quality of life. Postmenopausal osteoporosis is a well-studied subject, being a disease with an increasing prevalence. However, there is a large number of drugs to choose from for the treatment of postmenopausal osteoporosis. Bisphosphonates are the most used therapeutic choice but, with an almost 10-year clinical experience, RANKL inhibitor Denosumab is becoming more frequently used in practice, with great results. The main purpose of this review is to evaluate the efficacy of bisphosphonates compared with that of Denosumab by analyzing different parameters.
\end{abstract}

Matherials and methods. We included randomized studies that directly compared bisphosphonates to Denosumab after 1 year of treatment, which included data regarding the bone mineral density (BMD) and bone turnover markers (BTM) measured at baseline and after 12 months.

Results. Seven randomized studies were included in this review, combining a total of 4535 patients. In all 7 studies the changes in lumbar spine bone mineral density were statistically significant in favor of Denosumab. Denosumab also produced a decrease in bone turnover markers as early as 1 month from the beginning of the treatment. After 12 months of treatment the reduction percentage of BTM were similar between the two groups. The rate of adverse effects' occurrence is similar between the two groups.

Conclusion. Denosumab treated patients present an increase in bone mineral density after 12 months of treatment when compared to bisphosphonates. Both therapies have a similar reduction of bone turnover markers. The rate of adverse effects' occurrence during the 12 months of monitoring were also similar between the two drugs.

Keywords: postmenopausal osteoporosis, bisphosphonates, Denosumab, bone mineral density, bone turnover markers.

\section{Introduction}

Osteoporosis is a systemic skeletal disease characterized by reduced bone mass and bone tissue microarchitecture deterioration, which leads to a consecutive increase in bone fragility. Frequently it is an asymptomatic disease until a fracture occurs [1]. Osteoporosis has a higher prevalence among white women [1,2], being a preventable postmenopausal disease [3].

After menopause, the osteoclastic activity overcomes the osteoblastic activity.
This leads to the increase of bone resorption, followed by a global reduction in bone mass. This reduction of bone mass is subsequently followed by an increase in skeletal fragility and fracture risk [4].

The objective of the pharmacological treatment is to increase bone mass through modification of bone remodeling equilibrium. Until present day, none of the drugs used in the treatment of postmenopausal osteoporosis can fully restore skeletal density. 
The disease progression can be slowed by an early pharmacological treatment [5]. Bisphosphonates are the most frequently used drugs in osteoporosis treatment. They are used both for the prevention and for the pharmacological treatment of this disease, orally or intravenous[5]

\section{Table I. Major recommandations for clinician, adapted after the AACE/ACE Guidelines}

[6]

\begin{tabular}{|c|c|}
\hline \multicolumn{2}{|c|}{ General recommandations } \\
\hline $\begin{array}{l}\text { Counseling regarding the risk of osteoporosis and } \\
\text { fractures }\end{array}$ & Adequate intake of vitamin D and calcium \\
\hline Physical exercise & Risk factors evaluation \\
\hline \multicolumn{2}{|c|}{ Testing for bone mineral density (BMD) evaluation } \\
\hline $\begin{array}{l}\text { Women aged } 70 \text { and above and men aged } 80 \text { and } \\
\text { above with a } T \text { score } \leq-1\end{array}$ & $\begin{array}{l}\text { Women between } 65 \text { and } 69 \text { years and men between } \\
70 \text { and } 79 \text { years with a } T \text { score } \leq-1.5\end{array}$ \\
\hline \multicolumn{2}{|l|}{$\begin{array}{l}\text { Postmenopausal women and men aged } 50 \text { and above } \\
\text { with selected risk factors }\end{array}$} \\
\hline \multicolumn{2}{|c|}{ Monitoring } \\
\hline $\begin{array}{l}\text { Bone mineral density evaluation every } 1-2 \text { years after } \\
\text { treatment initiation and every } 2 \text { years after }\end{array}$ & $\begin{array}{l}\text { Biochemical markers evaluation for assessing } \\
\text { therapeutic efficiency }\end{array}$ \\
\hline \multicolumn{2}{|c|}{ Pharmacologic treatment initiation } \\
\hline Patients with clinical or asymptomatic fractures & Patients with a $\mathrm{T}$ score $\leq-2.5$ \\
\hline $\begin{array}{l}\text { Postmenopausal women or men aged } 50 \text { and above } \\
\text { with osteopenia (T score between }-1 \text { and }-2.5 \text { ) and a } 10 \\
\text { years hip fracture probability } \geq 3 \% \text { or a } 10 \text { year } \\
\text { osteoporosis related fracture } \geq 20 \% \text { based on the } \\
\text { absolute risk model of fracture approved by WHO } \\
\text { (www.NOF.org; www.shef.ac.uk/FRAX) }\end{array}$ & \\
\hline
\end{tabular}

Bisphosphonates have a pirophosphatelike structure, which are compounds incorporated in the bone matrix. Bisphosphonates suppress the osteoclastic Denosumab is a fully human monoclonal antibody for the receptor activator of nuclear factor kappa-B ligand (RANKL). Denosumab adheres to RANKL, leading to the inhibition of kappa-B nuclear factor's ability to initiate the growth of osteoclastic precursors and bone resorption realized by mature osteoclasts. RANKL holds an important role in the final process of osteoclastic formation, activity and survival $[7,10,11]$.

Bone metabolism is a continual cycle of bone formation and resorption. These two processes are regulated by the equilibrium between endogenous (cytokines, hormones, growth factors) and exogenous (the mechanical loading process) factors [12]. There are well known blood and urinary molecules that can measure bone metabolic activity. These markers are usually divided into two categories: bone formation biomarkers derived from osteoblastic activity (bone specific alkaline activity and number by inducing apoptosis. Through this effect, bisphosphonates reduce bone absorption, thus increasing bone mineral density $[7,8,9]$.

phosphatase, osteocalcin, N-terminal propeptide and C-terminal propeptide type I procollagen) and bone resorption biomarkers derived from type I collagen degradation (N-terminal telopeptide, Cterminal telopeptide etc.) [13].

Although there are many studies in the literature which assess bisphosphonates efficacy, as well as different other drugs used in the treatment of postmenopausal osteoporosis, including Denosumab $[14,15,16]$, the number of randomized controlled studies (RCT) is low [18-24].

The main purpose of this systematic analysis is to identify the studies that have compared the bisphosphonate and Denosumab efficacy and to establish which of these two treatments is better at increasing the bone mineral density of postmenopausal osteoporosis after 12 months. 


\section{Materials and methods}

The present analysis was conducted according to the PRISMA Statement [17]. The studies included in the analysis were searched in several databases (PubMed Central, Medline, Embase and Scopus) since their founding until february 2017. The search was limited to articles written in English. The search terms used were postmenopausal osteoporosis, Denosumab, bisphosphonates, bone mineral density and bone turnover markers. A filter for randomized controlled studies (RCT) and human studies was also used.

\section{Inclusion criteria}

All RCTs that directly compared bisphosphonates to Denosumab, used for at least 1 year in the treatment of postmenopausal osteoporosis were screened. Only fully published reports were included in the analysis, which contained data about the baseline and 12 months values of bone mineral density (BMD) and bone turnover markers (BTM).

The Consort checklist was used to critically evaluate the RCTs included in the present study.

\section{Exclusion criteria:}

Analyses or meta-analyses, conference papers and inconsistent data articles or with fewer than 12 months follow-up on the patients.

\section{Statistical analysis:}

The extracted data included study design, selection criteria, population demographics, type of intervention, baseline and 12 months BMD values, baseline and 12 months BTM values and the adverse effects that occurred due to the treatment. The results were processed in Review Manager 5.3.

\section{Results}

Seven RCTs [18-24] were included in the present analysis that presented the necessary inclusion criteria. A total of 4535 participants were included in these 7 RCTs. Five studies compared the efficacy of Denosumab vs Alendronate treatment $[18,19,21,22,23]$, one study compared Denosumab with Risedronate [20] and one study compared Denosumab with Ibandronate [24]. All studies were verified to identify the eventual discrepancies and prejudices in randomization using the Consort checklist. No such discrepancies or prejudices were identified.

We build a Flow diagram to present the aforementioned studies selection process (Fig. 1).

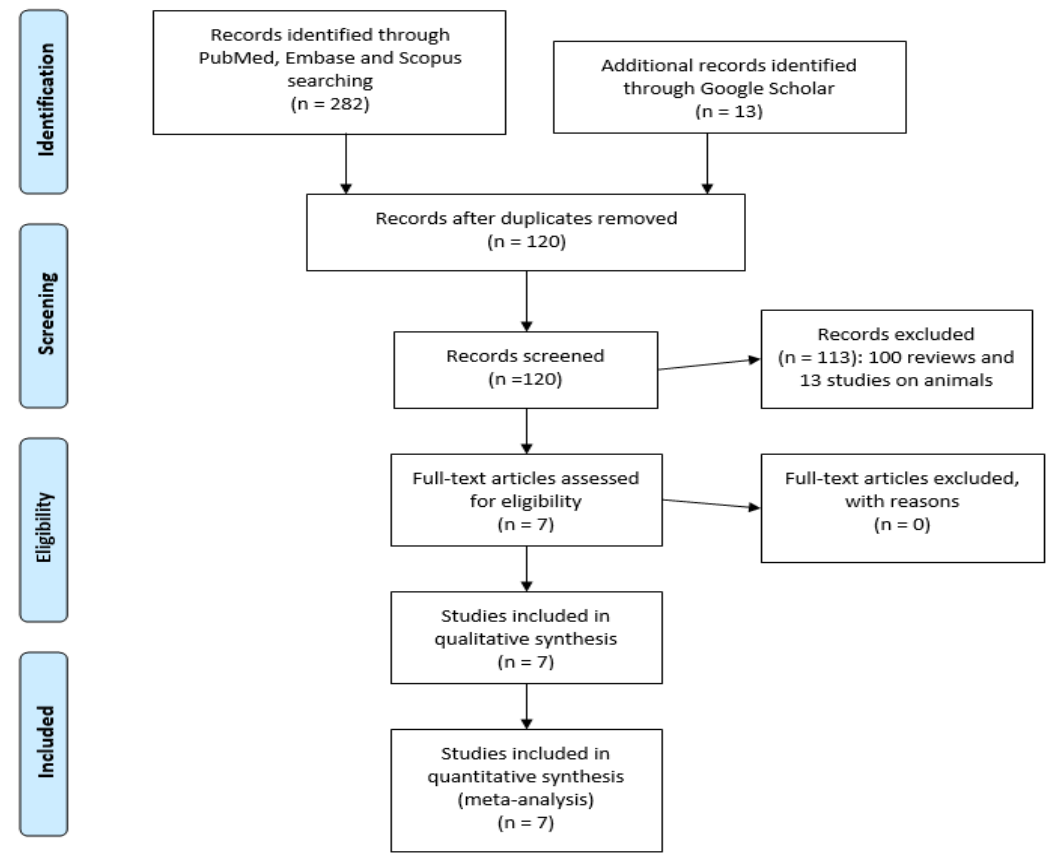

Figure 1. Flow diagram of the selected studies, after the PRISMA Statement [17] 
The demographic characteristic and the DXA test results at baseline as well as after
12 months of treatment are synthesized in Table II.

Table II. Patient characteristics of the included studies and BMD values measured on lumbar spine before and after 12 months treatment

\begin{tabular}{|c|c|c|c|c|c|c|c|}
\hline $\begin{array}{l}\text { First } \\
\text { author } \\
\text { (year) }\end{array}$ & $\begin{array}{l}\text { Number of } \\
\text { patients - } \\
\text { Denosumab }\end{array}$ & $\begin{array}{l}\text { Number } \\
\text { of } \\
\text { patients - } \\
\text { bisphosph } \\
\text { onates }\end{array}$ & $\begin{array}{l}\text { Mean age } \\
\text { denosumab/ } \\
\text { bisphosphonate }\end{array}$ & $\begin{array}{l}\text { Baseline BMD } \\
\text { values } \\
\text { measured at } \\
\text { lumbar spine } \\
\text { Denosumab }\end{array}$ & $\begin{array}{l}\text { Mean percentage } \\
\text { changes of BMD } \\
\text { values measured at } \\
\text { lumbar spine at } 12 \\
\text { months Denosumab }\end{array}$ & $\begin{array}{l}\text { Baseline BMD } \\
\text { values measured } \\
\text { at lumbar spine } \\
\text { bisphosphonates }\end{array}$ & $\begin{array}{l}\text { Mean percentage } \\
\text { changes of BMD values } \\
\text { measured at lumbar } \\
\text { spine at } 12 \text { months } \\
\text { bisphosphonates }\end{array}$ \\
\hline $\begin{array}{l}\text { Lewiecki M } \\
\text { (2007) }\end{array}$ & 319 & 47 & $62.3 \pm 8 / 62.8 \pm 8.2$ & $-2.1 \pm 0.1$ & 6.51 & $-2.15 \pm 0.15$ & 5.5 \\
\hline $\begin{array}{l}\text { Nakamura } \\
\mathrm{T}(2014)\end{array}$ & 449 & 230 & $\begin{array}{l}69.9 \pm 7.36 / 70.2 \pm 7.3 \\
1\end{array}$ & $-2.78 \pm 0.89$ & 9.1 & $-2.69 \pm 0.94$ & 7.5 \\
\hline $\begin{array}{l}\text { Roux C } \\
\text { (2013) }\end{array}$ & 435 & 435 & $67.8 \pm 7 / 67.7 \pm 6.8$ & $-2.2 \pm 1.2$ & 3.4 & $-2.3 \pm 1.1$ & 2.3 \\
\hline $\begin{array}{l}\text { McClung M } \\
\text { (2006) }\end{array}$ & 47 & 47 & $63.1 \pm 8.1 / 62.8 \pm 8.2$ & $-2.2 \pm 0.7$ & 4.85 & $-2.0 \pm 0.9$ & 3.6 \\
\hline $\begin{array}{l}\text { Kendler D } \\
(2009)\end{array}$ & 253 & 251 & $66.9 \pm 7.8 / 68.2 \pm 7.7$ & $-2.64 \pm 0.75$ & 3.03 & $-2.62 \pm 0.79$ & 1.85 \\
\hline $\begin{array}{l}\text { Brown JP } \\
(2008)\end{array}$ & 594 & 595 & $64.1 \pm 8.6 / 64.6 \pm 8.3$ & $-2.57 \pm 0.75$ & 5.3 & $-2.57 \pm 0.75$ & 4.2 \\
\hline $\begin{array}{l}\text { Recknor C } \\
\text { (2013) }\end{array}$ & 417 & 416 & $67.2 \pm 8.1 / 66.2 \pm 7.8$ & $-2.5 \pm 0.9$ & 4.1 & $-2.5 \pm 0.8$ & 2 \\
\hline
\end{tabular}

\section{Bone Mineral Density (BMD)}

All studies measured baseline lumbar spine BMD for both groups of patients (Denosumab and bisphosphonate treated). The 7 RCTs [18-24] registered changes in lumbar spine BMD values. Five studies $[19,20,22,23,24]$ also recorded changes in femoral neck BMD values and five studies $[18,19,21,22,23]$ in distal radius BMD values. Both groups obtained an improvement in lumbar spine BMD values after 12 months of treatment in every study, but the improvement was statistically significant in favor of Denosumab. Five studies $[19,20,22,23,24]$ recorded a statistically significant improvement in favor of Denosumab in femoral neck BMD values and five studies recorded a significant improvement, again in favor of Denosumab, in distal radius BMD values $[18,19,21,22,23]$. Using Review Manager 5.3, we conducted an analysis that shows that in all 7 studies Denosumab was statistically superior to bisphosphonates after 12 months of treatment. In this analysis we took into account only lumbar spine BMD values and for the purpose of consistency and lowering the bias risk, we used an unitary standard deviation (DS) due to the fact that not all study reported this value. The Forrest Plot graphic is presented in Figure 2.

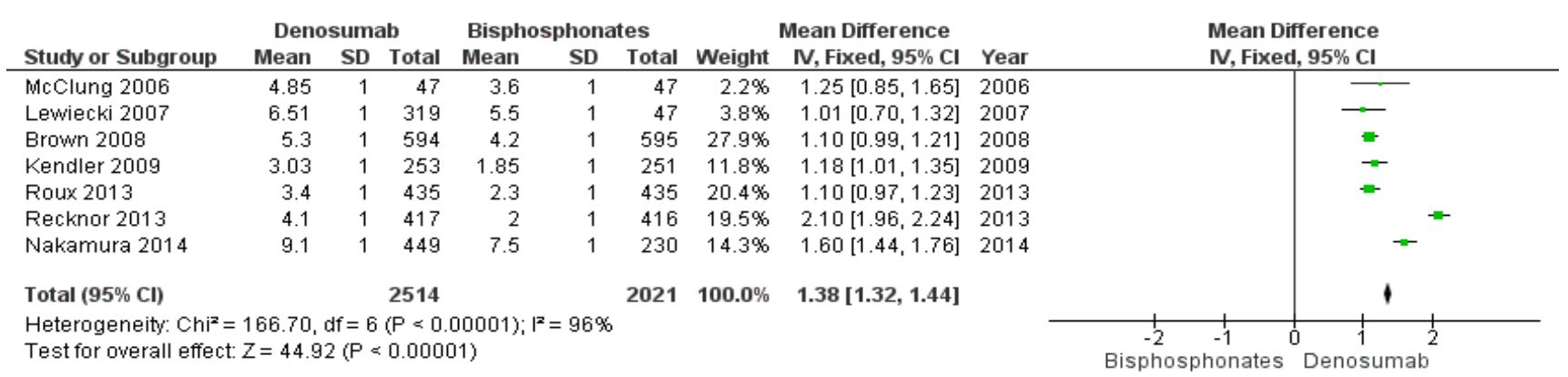

Figure 2. 12 months efficacy comparions between bisphosphonates and Denosumab therapy

\section{Bone Turnover Markers}

All seven included studies [18-24] measured the baseline values of bone turnover marker C-telopeptide, as well as the procentual change of this marker after 12 months of treatment. Four studies found a statistically significant reduction of C-telopeptide in favor of Denosumab 
$[18,20,22,24]$. Two studies didn't find any significant difference after 12 months of treatment between the two drug classes $[21,23]$, and a single study reported superior results in favor of bisphosphonates [19]. These results are presented in Table III.

Five of the included studies reduction in bone specific alkaline phosphatase. Of these five studies, three $[21,22,23]$ found Denosumab statistically superior to bisphosphonates, while two $[18,19]$ didn't find any significant difference between the two classes after 12 months of treatment.

$[18,19,21,22,23]$ reported the 12 month

Table III. Baseline bone turnover markers and their procentual change at 12 months of treatment

\begin{tabular}{|c|c|c|c|c|c|c|c|}
\hline Study & Treatment & $\begin{array}{l}\text { Baseline value of } \\
\text { C-telopeptide } \\
(\mathrm{ng} / \mathrm{ml})\end{array}$ & $\begin{array}{l}\text { Changes in C- } \\
\text { telopeptide } \\
\text { after } \\
\text { treatment }\end{array}$ & $\begin{array}{l}\text { Baseline } \\
\text { value of } \\
\text { NTx- } \\
\text { telopeptide }\end{array}$ & $\begin{array}{l}\text { Changes in } \\
\text { NTx- } \\
\text { telopeptide } \\
\text { after treatment }\end{array}$ & $\begin{array}{l}\text { Baseline value } \\
\text { of bone } \\
\text { alkaline } \\
\text { phosphatase }\end{array}$ & $\begin{array}{l}\text { Changes in bone } \\
\text { alkaline } \\
\text { phosphatase } \\
\text { after treatment }\end{array}$ \\
\hline \multirow{2}{*}{ Lowiecki, 2007} & Denosumab & 0.649 & $-70 \%$ & 63.8 & $-35 \%$ & 12.35 & $-60 \%$ \\
\hline & Alendronat & 0.675 & $-67 \%$ & 64.92 & $-45 \%$ & 12.44 & $-62 \%$ \\
\hline \multirow{2}{*}{ Brown JP, 2009} & Denosumab & 0.705 & $-74 \%$ & - & - & 54.17 & $-72 \%$ \\
\hline & Alendronat & 0.654 & $-76 \%$ & - & - & 50.5 & $-65 \%$ \\
\hline \multirow{2}{*}{ Nakamura T, 2014} & Denosumab & 0.64 & -6496 & - & - & - & $-50 x$ \\
\hline & Alendronat & 0.61 & $-72 \%$ & - & - & - & $-53 \%$ \\
\hline \multirow{2}{*}{ Roux C, 2014} & Denosumab & 0.32 & $-60.60 \%$ & & - & - & 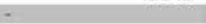 \\
\hline & Risedronat & 0.33 & $-22.50 \%$ & - & - & - & - \\
\hline \multirow{2}{*}{ Recknor, 2013} & Denosumab & 0.4 & $-59.90 \%$ & & & - & \\
\hline & Ibandronat & 0.4 & $-42 \%$ & - & - & - & - \\
\hline \multirow{2}{*}{ Mcclung, 2006} & Denosumab & $0.60 \pm 0.29$ & $-60 \%$ & & & $11.4 \pm 6.2$ & $66 \%$ \\
\hline & Alendronat & $0.68 \pm 0.26$ & $-62 \%$ & - & - & $12.4 \pm 6.2$ & $-61 \%$ \\
\hline \multirow{2}{*}{ Kendler, 2009} & Denosumab & 0.187 & $-11 \%$ & - & - & 21.24 & $-13 \%$ \\
\hline & Alendronat & 0.207 & $10 \%$ & - & - & 22.52 & $-0.50 \%$ \\
\hline
\end{tabular}

\section{Complications}

Several adverse effects were recorded, including cardiovascular side effects, gastroenterologic side effects, hypocalcemia, osteoarthicular side effects, malign or unspeciffied tumors. The majority of studies didn't find any statistically significant differences between the two treatment groups. One study [18] noted the presence of a major difference of gastroenterologic side effect between the Denosumab and Alendronate treated groups (38,8\% and $76 \%$ respectively). All studies [18-24] recorded the incidence of osteoarthicular side effects, the procentages between the two groups being similar. The results are presented in Table III.

Table IV. The incidence of adverse effects in Denosumab and bisphosphonate treated groups

\begin{tabular}{|c|c|c|c|c|c|c|c|c|c|c|c|c|c|c|}
\hline \multirow[t]{2}{*}{$\begin{array}{l}\text { Study / Adverse } \\
\text { events }\end{array}$} & \multicolumn{2}{|c|}{ Lewiecki, 2007} & \multicolumn{2}{|c|}{ Brown JP, 2009} & \multicolumn{2}{|c|}{$\begin{array}{c}\text { Nakamura, } \\
2014\end{array}$} & \multicolumn{2}{|c|}{ Roux, 2014} & \multicolumn{2}{|c|}{ Recknor, 2013} & \multicolumn{2}{|c|}{ McClung, 2006} & \multicolumn{2}{|c|}{ Kendler, 2009} \\
\hline & 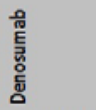 & 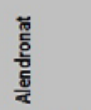 & 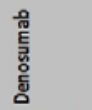 & 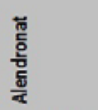 & 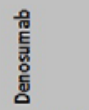 & 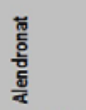 & 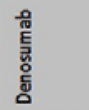 & 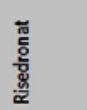 & $\begin{array}{l}\text { 邑 } \\
\text { E⿸\zh14⿰⿺乚一匕 } \\
\text { 임 }\end{array}$ & 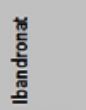 & 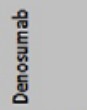 & 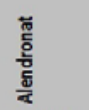 & 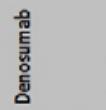 & 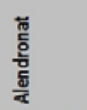 \\
\hline $\begin{array}{l}\text { Total adverse } \\
\text { events }\end{array}$ & $92.00 \%$ & $93.50 \%$ & $80.90 \%$ & $82.30 \%$ & $94.30 \%$ & $94.60 \%$ & $62.70 \%$ & $68.30 \%$ & $59.60 \%$ & $56.10 \%$ & $87.30 \%$ & $91.30 \%$ & $77.90 \%$ & $78.70 \%$ \\
\hline $\begin{array}{l}\text { Cardiovascular } \\
\text { adverse events }\end{array}$ & $10.50 \%$ & $10.90 \%$ & - & - & $14.30 \%$ & $8.70 \%$ & - & - & $1.70 \%$ & $0.70 \%$ & $0.90 \%$ & $0 \%$ & - & - \\
\hline Infections & $34.70 \%$ & $30.40 \%$ & $0 \%$ & $0.20 \%$ & $60.20 \%$ & $54.10 \%$ & $1.20 \%$ & $1.20 \%$ & $1.70 \%$ & $1.50 \%$ & $0.60 \%$ & $0 \%$ & $43.90 \%$ & $37.30 \%$ \\
\hline $\begin{array}{l}\text { Gastrointestinal } \\
\text { adverse events }\end{array}$ & $38.80 \%$ & $76 \%$ & $27.70 \%$ & $28.70 \%$ & - & - & $0.20 \%$ & $0.20 \%$ & $1.70 \%$ & $0.20 \%$ & - & - & $22.90 \%$ & $24.10 \%$ \\
\hline Hypocalcemia & - & - & $=$ & - & $0.40 \%$ & $0.80 \%$ & - & - & $0.20 \%$ & $0.20 \%$ & - & - & - & - \\
\hline $\begin{array}{l}\text { Osteoarticular } \\
\text { disorders }\end{array}$ & $73.50 \%$ & $74 \%$ & $19.60 \%$ & $16 \%$ & $0 \%$ & $0 \%$ & $5.40 \%$ & $4 \%$ & $3.60 \%$ & $3.20 \%$ & $3.80 \%$ & $2.20 \%$ & $3.20 \%$ & $1.60 \%$ \\
\hline $\begin{array}{l}\text { Malignancies or } \\
\text { unspecified }\end{array}$ & - & - & $3.50 \%$ & $2.60 \%$ & $1.90 \%$ & $0.80 \%$ & $1.40 \%$ & $1.90 \%$ & $1.20 \%$ & $1.50 \%$ & $1.90 \%$ & $0 \%$ & $3.60 \%$ & $3.60 \%$ \\
\hline
\end{tabular}

\section{Discussion}

From our knowledge the current analysis is the first to compare directly the 12 month efficacy of Denosumab versus bisphosphonates using such a large number of participants.

Denosumab prevents the RANKL interaction with its receptors, leading to the obstruction of osteoclastic maturation, function and survivability [7,10,11]. Bisphosphonates adhere to calcium bone hydroxiapatite, thus reducing bone resorption by affecting the osteoclasts' function and survivability.

There isn't any scientific data regarding the interaction between the osteoclastic 
maturation and bisphosphonate until present day.

X-ray osteodensitometry (DXA) is the gold standard for the diagnosis of osteoporosis by analysing the bone mineral density [1]

All analyzed studies [18-24] observed a superior increase of lumbar spine, total hip, femoral neck and distal radius BMD values in the Denosumab treated group (as shown in Table II).

BMD is a frequently used marker to evaluate the efficacy of osteoporosis treatment. Reevaluation using DXA more often than once every 2 years isn't indicated, as the treatment effect is relatively small compared to the test's precision [6]. There hasn't been established any precise and consistent relation between the increase of BMD values and the decrease of specific fractures risk [5].

BTM evaluation is a non-invasive method for the monitoring of treatment efficacy [1]. The biochemical analyses can be used to monitor bone metabolism, the proteins and enzymes being released during the bone formation and resorbtion phases. The. analysis of these markers could lead to a very specific and sensitive evaluation of bone formation and resorption rate $[25,26]$. The used markers are C-terminal telopeptid type I collagen (CTX) for the bone. resorption and bone specific alkaline phosphatase (BSAP) for the bone formation [12,13].

BTM reflect the metabolic effect of the usect. drugs on bone turnover. Bone resorption inhibition leads to a decrease of bone resorption markers followed by a plateau. By contrast, bone formation continues at the same rate. BTM changes depend on the drug administered. Denosumab administered subcutaneously inhibits the bone resorption as early as 12 hours after administration. Bisphosphonates administered intravenously inhibit bone resorption and lower resorption. markers more rapidly than oral administration [25,26,27].

The data we obtained are consistent with the data obtained by other meta-analyses $[28,29]$. We can therefore affirm that
Denosumab is more efficient than bisphosphonates in increasing the bone mineral density values after 12 months of treatment. Neither of the drug classes had a decreased rate of fracture incidence. Future inquiries will need to include a longer patient monitorization to provide a higher accuracy of results.

\section{Conclusion}

The administration of Denosumab in the treatment of postmenopausal osteoporosis leads to a superior increase of bone mineral density and decrease of bone turnover markers compared to bisphosphonates. The rate of adverse effects' occurrence is similar between the two therapies. In order to establish a clear difference future studies will need to monitor patients for more than 24 months.

\section{Bibliography}

NIH Consensus Development Panel on Osteoporosis Prevention, Diagnosis and Therapy. Osteoporosis prevention, diagnosis and therapy. JAMA 2001;285:785-795.

Meunier PJ, Vignot E, Garnero P, Confavreux E, Paris E, Liu-Leage S, Sarkar S, Liu T, Wong M, Draper MW. Treatment of postmenopausal women with osteoporosis or low bone density with raloxifene. Raloxifene Study Group. Osteoporos Int 1999;10:330336.

Simon JA. ACOG practice bulletin. Clinical management guidelines for obstetriciangynecologists. Obstet Gynecol 2003;103:203-216.

Riggs BL, Melton LJ. The prevention and treatment of osteoporosis. N Engl J Med 1992;327:620-627.

Cosman F, de Beur SJ, LeBoff MS, Lewiecki EM, Tanner B, Randall S, Lindsay R. Clinician's Guide to Prevention and Treatment of Osteoporosis. Osteoporos Int 2014;25(10):2359-2381.

Camacho PM, Petak SM, Binkley N, Clarke BL, Harris ST, Hurley DL, Kleerekoper M, Lewiecki ME, Miller PD, Narula HS, Watts NB. American Association of Clinical Endocrinologists and American College of Endocrinology Clinical Practice Guidelines for the Diagnosis and Treatment of Postmenopausal Osteoporosis. Endocrine Practice 2016, 22(9):1111-1118.

Kasper D, Hauser S, Jameson L, Fauci A, Longo D, Loscalzo J. Harrison's Principles of Internal Medicine 19th Edition. McGraw-Hill Education 2015;425:2501. Russell RG, Watts NB, Ebetino FH, Rogers MJ. Mechanisms of action of bisphosphonates: similarities and differences and their potential influence on clinical efficacy. Osteoporos Int 2008;19:733-759. 
9. Hughes DE, MacDonald BR, Russell RGG, Gowen M. Inhibition of osteoclast-like cell formation by bisphosphonates in long-term cultures of human bone marrow. J Clin Invest 1989;83:1930-1935.

10. Sordillo EM, Pearse RN. RANK-Fc: a therapeuti antagonist for RANK-L in myeloma. Cance 2003;97:802-812.

11. Schwarz EM, Ritchlin CT. Clinical development c anti-RANKL therapy. Arthritis Res The 2007;9(Suppl 1):S7.

12. Cavalier E, Bergmann P, Bruyere O, Delanaye P22. Kendler, DL, Roux C, Benhamou CL, Brown JP, Durnez A, Devogelaer JP, Ferrari SL, Gielen E, Goemare S, Kaufman JM, Nzeusseu Toukap A, Reginster JY, Rousseau AF, Rozenberg S, Scheen AJ, Body JJ. The role of biochemical of bone turnover markers in osteoporosis and metabolic bone disease: a consensus paper of the Belgian Bone Club23. Osteoporos Int 2016.

13. $\mathrm{S}$, Eastell $\mathrm{R}$, Bruyère $\mathrm{O}$ et al. Markers of bone turnover for the prediction of fracture risk and monitoring of osteoporosis treatment: a need for international reference standards. Osteoporos Int 2011;22:391-420.

14. van de Glind EM, Willems HC, Eslami S et al. Estimating the time to benefit for preventive drugs with the statistical process control method: ap4. example with alendronate. Drugs Aging. 2016;33:347-353.

15. Chao M, Hua Q, Yingfeng Z et al. Study on the role of zoledronic acid in treatment of postmenopausal osteoporosis women. Pak J Med Sci. 2013;29:13811384.

16. Cummings SR, San Martin J, McClung MR, Siris ES, Eastell R, Reid IR, Delmas P, Zoog HB, Austin M25. Wang A et al. Denosumab for prevention of fractures in postmenopausal women with osteoporosis. N Engl J Med. 2009;361:756-765.

17. Liberati A, Altman DG, Tetzlaff J. The PRISMA group. Preferred reporting items for systematic reviews and meta-analyses: the PRISMA statement26. PLoS Med. 2009;6(7):e1000097.

18. Lewiecki EM Miller PD, McClung MR, Cohen SB, Bolognese MA, Liu Y, Wang A, Siddhanti S27. Fitzpatrick LA. Two-Year Treatment With Denosumab (AMG 162) in a Randomized Phase 2 Study of Postmenopausal Women With Low BMD. 28. Bone Miner Res 2007;22:1832-1841.

19. Nakamura $T$, Matsumoto $T$, Sugimoto $T$, Hosoi $T$, Miki T, Gorai I, ... Fukunaga M. Clinical Trials Express: Fracture Risk Reduction With Denosumab in Japanese Postmenopausal Women and Men With Osteoporosis: Denosumab Fracture Interventiong. Randomized Placebo Controlled Trial (DIRECT). The Journal of Clinical Endocrinology and Metabolism 2014;99(7):2599-2607.

20. Roux C, Hofbauer LC, Ho PR, Wark JD, Zillikens MC, Fahrleitner-Pammer A, Hawkins F, Micaelo M, Minisola S, Papaioannou N, Stone M, Ferreira I, Siddhanti S, Wagman RB, Brown JP. Denosumab compared with risedronate in postmenopausal women suboptimally adherent to alendronate therapy: Efficacy and safety results from a randomized openlabel study. Bone 2013;58:48-54.

1. McClung MR, Lewiecki ME, Cohen SB, Bolognese MA, Woodson GC, Moffett AH, Peacock M, Miller PD, Lederman SN, Chesnut CH, Lain D, Kivitz AJ, Holloway DL, Zhang C, Peterson MC, Bekker PJ. Denosumab in Postmenopausal Women with Low Bone Mineral Density. N Engl J Med 2006;354:821831.

Lillestol M, Siddhanti S, Man HS, Martin JS, Bone HG. Effects of denosumab on bone mineral density and bone turnover in postmenopausal women transitioning from alendronate therapy. J Bone Miner Res 2010;25:72-81.

Brown JP, Prince R, Deal C, Recker R, Kiel DP, de Gregorio LH, Hadji P, Hofbauer LC, Alvaro-Gracia JM, Wang H, Austin M, Wagman RB, Newmark R, Libanati C, San Martin J, Bone HG. Comparison of the effect of Denosumab and Alendronate on BMD and Biochemical Markers of Bone Turnover in Postmenopausal Women with Low Bone Mass: A Randomized, Blinded, Phase 3 Trial. J Bone Miner Res 2009;24:153-161.

4. Recknor C, Czerwinski E, Bone HG, Bonnick S, Binkley N, Palacios S, Moffett A, Siddhanti S, Ferreira I, Ghelani P, Wagman RB, Hall JW, Bolognese MA, Benhamou CL. Denosumab Compared With Ibandronate in Postmenopausal Women Previously Treated With Bisphosphonate Therapy: A Randomized Open-Label Trial. Obstet \& Gynecol 2013;121(6):1291-1299.

. Nishizawa Y, Ohta H, Miura M, Inaba M, Ichimura S, Shiraki M, Takada J, Chaki O, Hagino H, Fujiwara S, Fukunaga M, Miki T, Yoshimura N. Guidelines for the use of bone metabolic markers in the diagnosis and treatment of osteoporosis (2012 edition). J Bone Miner Metab 2013;31:1-15.

Canalis E, Giustina A, Bilezikian JP. Mechanisms of anabolic therapies for osteoporosis. N Engl J Med 2007;357:905-916.

Szulc P. The role of bone turnover markers in monitoring treatment in postmenopausal osteoporosis. Clin Biochem 2012;45:907-919.

Lin T, Wang C, Cai XZ, Zhao X, Shi MM, Ying ZM, Yuan FZ, Guo C, Yan SG. Comparison of clinical efficacy and safety between denosumab and alendronate in postmenopausal women with osteoporosis: a meta-analysis. Int $\mathrm{J}$ Clin Pract 2012;66(4):399-408.

. Benjamin B, Benjamin MA, Swe M, Sugathan S. Review on the comparison of effectiveness between denosumab and bisphosphonates in post-menopausal osteoporosis. Osteoporosis and Sarcopenia 2016:2(2):77-81. 